Journal of Business \& Economic

Statistics

플

\section{Journal of Business \& Economic Statistics}

ISSN: 0735-0015 (Print) 1537-2707 (Online) Journal homepage: http://www.tandfonline.com/loi/ubes20

\title{
Market-Based Measures of Monetary Policy Expectations
}

\section{Refet S Gürkaynak, Brian P Sack \& Eric T Swanson}

To cite this article: Refet S Gürkaynak, Brian P Sack \& Eric T Swanson (2007) Market-Based Measures of Monetary Policy Expectations, Journal of Business \& Economic Statistics, 25:2, 201-212, DOI: 10.1198/073500106000000387

To link to this article: http://dx.doi.org/10.1198/073500106000000387

册Published online: 01 Jan 2012.

Submit your article to this journal $\asymp$

Џlll Article views: 392

Q View related articles $₫$

4 Citing articles: 66 View citing articles 주다. 


\title{
Market-Based Measures of Monetary Policy Expectations
}

\author{
Refet S. GÜRKAYNAK \\ Economics Department, Bilkent University, Ankara, Turkey (refet@bilkent.edu.tr)
}

\author{
Brian P. SACK \\ Macroeconomic Advisers LLC, Washington, DC 20006 (sack@macroadvisers.com)
}

\author{
Eric T. SWANSON \\ Economic Research, Federal Reserve Bank of San Francisco, San Francisco, CA 94105 \\ (eric.swanson@sf.frb.org)
}

\begin{abstract}
A number of recent articles have used different financial market instruments to measure near-term expectations of the federal funds rate and the high-frequency changes in these instruments around Federal Open Market Committee announcements to measure monetary policy shocks. This article evaluates the empirical success of a variety of financial market instruments in predicting the future path of monetary policy. All of the instruments we consider provide forecasts that are clearly superior to those of standard time series models at all of the horizons considered. Among financial market instruments, we find that federal funds futures dominate all the other securities in forecasting monetary policy at horizons out to six months. For longer horizons, the predictive power of many of the instruments we consider is very similar. In addition, we present evidence that monetary policy shocks computed using the current-month federal funds futures contract are influenced by changes in the timing of policy actions that do not influence the expected course of policy beyond a horizon of about six weeks. We propose an alternative shock measure that captures changes in market expectations of policy over slightly longer horizons.
\end{abstract}

KEY WORDS: Federal Reserve; Futures; Monetary policy.

\section{INTRODUCTION}

Measures of monetary policy expectations are an important element of many empirical articles in the macroeconomics and finance literatures. Lately, a strand of literature has focused on measuring policy expectations from asset prices. In this context, market interest rates have often been used to parse out the unexpected component of policy decisions-often referred to as monetary policy shocks. Krueger and Kuttner (1996), Rudebusch (1998), and Brunner (2000) were among the first to explore this approach, and many others have subsequently followed their lead.

An important issue in this approach is the choice of the asset to be used in measuring expectations. The abundance of short-term interest rates that potentially measure federal funds rate expectations has led to a proliferation of asset pricebased monetary policy expectation measures, many times with an assertion that a particular measure is better than others with little evidence offered in support. Kuttner (2001) and Faust, Swanson, and Wright (2004) used the current-month federal funds futures contract, Bomfim (2003) and Poole and Rasche (2000) the month-ahead federal funds futures contract, Cochrane and Piazzesi (2002) the one-month eurodollar deposit rate, Ellingsen and Soderstrom (2004) the three-month Treasury bill rate, and Rigobon and Sack (2002) the three-month eurodollar futures rate.

This article evaluates the ability of these and other financial market instruments to capture expectations of the future course of monetary policy and, correspondingly, to measure monetary policy shocks. Each of the financial market instruments we consider-term federal funds loans, federal funds futures, term eurodollar deposits, eurodollar futures, Treasury bills, and commercial paper-differ with respect to their risk and liquidity characteristics, so that it is not clear a priori which should provide the best forecast of the future course of monetary policy. For example, U.S. Treasury bills are regarded by market participants as being the safest and among the most liquid of the instruments in our study. Nonetheless, they may not be the best measure of monetary policy expectations because the price that investors are willing to pay for safety and liquidity may vary over time. The same kinds of problems arise with our other securities, which tend to be riskier and less liquid than Treasury bills. In this article, we perform a comprehensive set of empirical tests to determine which financial market instrument-or combination of instruments-forecasts the federal funds rate the best at various horizons. Those instruments that have the highest predictive power for the federal funds rate are taken to be the best measures of monetary policy expectations.

We find that all of the financial market instruments in our study provide forecasts that are clearly superior to those of standard time series models, such as a Bayesian VAR. Among our financial market securities, federal funds futures dominate all other securities for predicting changes in the federal funds rate at horizons out to six months. For longer forecast horizons, we find that, perhaps surprisingly, the predictive power of many of the instruments we consider is very similar. Even at these longer horizons, though, the predictive power of these financial market instruments is substantial, with $R^{2}$ of about $40 \%$ for federal funds rate changes.

In the Public Domain Journal of Business \& Economic Statistics April 2007, Vol. 25, No. 2 DOI 10.1198/073500106000000387 
The superior forecasting performance of federal funds futures may, in part, reflect that they are explicitly linked to the federal funds rate. However, an explicit link does not necessarily imply that these instruments will provide better forecasts. For example, to the extent that federal funds futures are less liquid than other securities, then the forecasts they provide might be expected to perform more poorly, because of the wedges introduced by larger transaction costs (bid-ask spreads, "slippage" of price against large orders) and the greater risks associated with being unable to adjust or unwind a position quickly in response to incoming news. This was arguably the case both for Consumer Price Index (CPI) futures in the 1980s (which were introduced on the Coffee, Sugar, and Cocoa Exchange in June 1985 but were delisted in April 1987 because of extremely low trading volumes and open interest) and for Treasury inflation-indexed securities (TIPS) in the first few years after their introduction in 1997: Despite being explicitly linked to CPI inflation, both securities were generally regarded as providing poor measures of inflation expectations due, in part, to their low level of liquidity. Moreover, even though the other instruments we consider are not explicitly linked to the federal funds rate, they are extremely close substitutes, so that the linkage to federal funds rate expectations should be very tight. This makes them prime candidates for improving or even dominating forecasts based on federal funds futures alone.

Our results have important implications for market-based measures of monetary policy shocks, or the surprise component of monetary policy announcements. In many of the articles using market-based measures of policy expectations, policy shocks are measured by revisions to near-term expectations of the federal funds rate at the time of policy decisions. Based on our findings, it appears that the best measure of shocks to the immediate policy setting would be based on federal funds futures rates, as in the approach described by Kuttner (2001).

One potential shortcoming of such a measure, as also discussed by Kuttner (2001), is that shocks to the immediate policy setting can be influenced by shifts in the timing of policy actions that have little consequence for the expected course of monetary policy beyond the horizon of a few weeks. Such policy surprises would presumably have limited effects on asset prices or the economy. We, therefore, compute an alternative measure of policy shocks based on the rates on federal funds and eurodollar futures with slightly longer horizons. This new measure captures changes to the expected near-term policy path rather than to the immediate policy setting, and, hence, it is less influenced by the timing of policy actions.

The remainder of this article proceeds as follows. Section 2 provides an introduction to each of our financial market instruments and discusses its risk, liquidity, and available maturities. Section 3 derives our estimation framework and discusses the methodology. Section 4 estimates the forecasting power of each of our financial market instruments for the federal funds rate and the estimated average risk premium for each instrument. It also shows that the predictive power of the financial instruments clearly dominates that of a Bayesian VAR. Section 5 traces out the implications of these results for the measurement of monetary policy shocks and suggests an alternative shock measure that is less susceptible to surprises in the exact timing of FOMC decisions. Section 6 concludes. A technical appendix provides details of our benchmark Bayesian VAR estimation and forecasting methodology.

\section{DATA}

Expectations about the near-term course of monetary policy are an important determinant of most short-term market interest rates. This relationship is very explicit in some cases, such as for federal funds futures, which are contracts where the payout on the instrument is directly linked to the realized level of the federal funds rate. In other cases, the relationship arises because investors can substitute between different strategies for obtaining short-term returns. In this section, we review a number of market interest rates that could be used to measure monetary policy expectations. The discussion touches on characteristics of the underlying instruments that might influence their information content, including the liquidity of the instruments and the potential size of the risk premia that also influence these rates. For additional details, see the data appendix in Gürkaynak, Sack, and Swanson (2006) and Stigum (1990).

Term Federal Funds Loans. The federal funds rate-the policy instrument of the Federal Reserve-is the rate at which banks make unsecured loans to one another on an overnight basis. But banks can also borrow and lend to one another for longer periods in the federal funds market, called term federal funds loans. Because these loans are unsecured, they are among the riskier instruments we consider-and, hence, they may embed a larger credit risk premium than that found in overnight federal funds loans. The market for loans with maturities of up to six months is reasonably active and liquid (though nowhere near the levels for the overnight federal funds market), but there is virtually no activity beyond that horizon.

Federal Funds Futures. These futures contracts, traded on the Chicago Board of Trade (CBOT) exchange, have a payout at maturity based on the average effective federal funds rate that is realized for the calendar month specified in the contract. Thus, the price of these securities is closely linked to financial market expectations for the average federal funds rate for the month in question. The counterparty credit risk in these instruments is relatively small due to the CBOT's daily marking-to-market and collateral requirements. Over most of our sample, federal funds futures contracts were extremely liquid at expirations out to three months and still fairly liquid out to five or six months, but liquidity dropped off sharply at horizons beyond that. However, in the past few years, liquidity and open interest in federal funds futures has soared, with significant liquidity extending out even to nine or ten months.

Term Eurodollar Deposits. Term eurodollars are dollardenominated time deposits held at financial institutions outside the United States, particularly London. As with term federal funds, these loans are unsecured and, thus, suffer from some probability of default. Moreover, the set of participants in the eurodollar market may differ in credit quality from those in the term federal funds market, which could potentially drive an additional wedge between eurodollar rates and the corresponding term federal funds rates. Nevertheless, many large banks do actively substitute between domestic deposits and eurodollar deposits, suggesting that the linkage is fairly tight. Eurodollar deposit maturities range from overnight to several years, although volumes fall off considerably after one year-indeed, the British Bankers Association does not provide quotes for eurodollar deposit rates [or London Interbank Offered Rates (LIBOR)] for maturities longer than one year. 
Eurodollar Futures. These futures contracts, traded on the Chicago Mercantile Exchange (CME), are the most actively traded futures contracts in the world. They have a payout at maturity based on the spot three-month LIBOR on the day of expiration. As with federal funds futures, the counterparty credit risk is relatively small due to daily marking-to-market and collateral requirements. Quarterly contracts are available out to horizons of 10 years, and liquidity is exceptionally high for contracts expiring over the first several years. Of course, the value of these contracts is directly tied to LIBOR rather than to the federal funds rate, and, hence, the success of these contracts for predicting U.S. monetary policy depends, as with term eurodollars, on the extent to which LIBOR tracks the federal funds rate in the markets.

Treasury Bills. U.S. Treasury bills are among the safest and most liquid securities in the world. At various times, the U.S. Treasury has issued bills with maturities ranging anywhere from one month to one year, but it has only consistently offered three-month and six-month securities over our sample period. Treasury bills are viewed as being essentially free of default risk and have some tax advantages (they are not taxed at the state level), whereas the federal funds rate is a private shortterm interest rate that has some default risk and no tax advantages, which introduces a potential shortcoming of bill rates as a predictor of future federal funds rates. Nevertheless, substitution between these short-term rates is extensive and the linkage between them is thought to be very tight.

Commercial Paper. Commercial paper (CP) is unsecured debt with maturity shorter than 270 days issued by investmentgrade corporations. We only consider the highest-grade (A1/P1) class of commercial paper in our analysis. As with term federal funds and eurodollars, these loans are subject to some probability of default, but default is less likely for CP because issuers are typically required to have a committed line of credit from a major financial institution that can be used to repay lenders in an emergency. CP issuance is concentrated at maturities of less than 90 days, with an average maturity of around 30 days. The linkage between $\mathrm{CP}$ and federal funds arises because investors can substitute between holding $\mathrm{CP}$ and making federal funds loans (or holding other short-term assets whose rates are influenced by the federal funds rate).

\section{EMPIRICAL SPECIFICATION}

The ability of investors to substitute between different financial market instruments suggests, as does standard asset pricing theory, that the rate of return $r_{t+t+k}^{m}$ on a market instrument $m$ from day $t$ to day $t+k$ is equal to the expected rate of return from an investment strategy of rolling over overnight loans in the federal funds market from day $t$ to day $t+k$, plus a risk premium $\rho_{t, t+k}^{m}$ :

$$
r_{t, t+k}^{m}=E_{t}\left[\prod_{j=t}^{t+k-1}(1+f f j)-1\right]+\rho_{t, t+k}^{m},
$$

where $f f_{j}$ is the overnight federal funds rate on day $j$. One may derive (1) directly from standard asset pricing theory-see, for example, Campbell, Lo, and MacKinlay (1997) for a general analysis and Gürkaynak et al. (2002) for a specific derivation.
We rearrange terms in (1) to arrive at the following regression equation:

$$
\overline{f f}_{t, t+k}=\alpha+\beta r_{t, t+k}^{m}+\varepsilon_{t},
$$

where, to simplify notation, we let $\overline{f f}_{t, t+k}=\left[\prod_{j=t}^{t+k-1}(1+\right.$ $\left.\left.f f_{j}\right)-1\right]$ denote the (compounded) return to the strategy of rolling over federal funds loans and where the risk premium $\rho_{t, t+k}^{m}$ has been included in the regression residual (with its average level incorporated into the constant). Note that the risk premium, which is measured in (1) and (2) relative to the federal funds rate, can, in principle, be negative for some assets, a possibility that we will confirm empirically for Treasury bills later.

Equation (2) is a standard interest rate forecasting regression that has been widely used in the literature. We will be interested, in particular, in the $R^{2}$ and root mean squared forecast error (RMSE) from regression (2), as these directly measure the usefulness of our various financial market instruments for forecasting the federal funds rate.

A common assumption in the literature, referred to as the "expectations hypothesis," is that the risk premium $\rho_{t, t+k}^{m}$ is constant over time and, thus, depends only on the security $m$ and its maturity $k$. We do not require this assumption for this article, because we are interested in the forecasting performance of regression (2) rather than structural estimates of $\beta$. To the extent that the risk premium $\rho_{t, t+k}^{m}$ on security $m$ varies over time, it will deteriorate the forecasting performance of security $m$ in regression (2) (and tend to lead to an estimate of $\beta$ that is different from unity to the extent that $\rho_{t, t+k}^{m}$ is correlated with $r_{t, t+k}^{m}$ ) and cause us to favor other financial market instruments for forecasting the federal funds rate. Thus, we will naturally be led to favor instruments for which time-varying risk premia are less of an issue. Finally, if we impose $\beta=1$ in regression (2), then the estimated value of $\alpha$ will be $-\rho$, the (negative of the) average risk premium on the asset, which we will also report for each financial market instrument.

Two final issues arise in estimating (2). First, some of the instruments we consider are term interest rates (term federal funds, eurodollar deposits, Treasury bills, commercial paper), whereas others are futures rates (federal funds futures, eurodollar futures), which forecast the federal funds rate starting at some future date $t+j$. To be able to make direct comparisons across the various instruments we consider, we back out the implied forward rates from all of our term interest rates and compare the predictive power across instruments in terms of their forward rate predictions, as follows. Let $r_{t, t+j, t+j+k}^{m}$ denote the implied interest rate on security $m$ on date $t$ for a loan beginning on day $t+j$ and ending on day $t+j+k$. A simple modification of the preceding analysis yields the regression equation:

$$
\overline{f f}_{t+j, t+j+k}=\alpha+\beta r_{t, t+j, t+k}^{m}+\varepsilon_{t} .
$$

The second issue that arises in estimating (3) is that if the nominal rates of return in the equation are integrated variables (or nearly so), the estimated coefficients will be dominated by their long-run relationship (the cointegrating vector), regardless of their short-run relationships. Because we are primarily interested in their short-run relationships-that is, in the ability of 
market rates to predict the federal funds rate over the next several months or quarters-we follow common practice and "stochastically detrend" (2) by subtracting off the current level of the federal funds rate from both sides of the equation:

$$
\overline{f f}_{t+j, t+j+k}-f f_{t}=\alpha+\beta\left(r_{t, t+j, t+k}^{m}-f f_{t}\right)+\varepsilon_{t} .
$$

Equation (4) serves as the basis for all of the empirical work that follows. Each regression also includes two dummy variables to capture potential systematic spikes in risk premia: a Y2K dummy variable that is nonzero for the forward rate spanning the century date change and a year-end dummy variable that is nonzero for forward rates spanning the end of any year. The year-end dummy is included because firms sometimes attempt to make their year-end balance sheets look stronger for reporting purposes (they engage in "window dressing"); as a result, firms as a whole may be more willing to hold some assets than others over the year end, which can affect their prices. (Downing and Oliner 2004 showed that year-end effects are particularly important for commercial paper.)

\section{THE PREDICTIVE POWER OF FINANCIAL MARKET INSTRUMENTS}

We now apply regression specification (4) to our various financial market instruments. We begin our sample in 1994, because the FOMC (the Federal Open Market Committee, which is the policymaking body of the Federal Reserve) began explicitly announcing its target for the federal funds rate at that time, and, thus, there is a potential structural break in financial market forecasting performance beginning with that date. We consider forecast horizons for each security ranging from one month ahead to four quarters ahead, although data availability prevent us from considering some forecast horizons for some securities (as discussed in Sec. 2). The horizons considered for each instrument are summarized in Table 1.

\subsection{Results for Monthly Frequency Instruments}

We perform our first set of regressions at a monthly frequency (sampling on the next-to-last business day of each month), computing one-month forward rates for horizons ranging from one to six months ahead. Unfortunately, eurodollar futures have quarterly expiration dates and our Treasury bill data include only quarterly maturities, so we must exclude these two instruments in this first round.

Table 1. Data Description

\begin{tabular}{lc}
\hline \hline Instrument & Horizon covered \\
\hline Term federal funds loans & $1-12$ months \\
Federal funds futures & $1-6$ months \\
Term eurodollar deposits & $1-12$ months \\
Eurodollar futures & $1-4$ quarters \\
Treasury bills & $1-2$ quarters \\
Commercial paper & $1-3$ months \\
\hline
\end{tabular}

NOTE: Data for federal funds futures are from CBOT, eurodollar futures from CME, term federal funds from Bloomberg, term eurodollar deposits from the British Bankers Association, constant-maturity Treasury Bills from the U.S. Treasury Department, and commercial paper from the Federal Reserve's H.15 data release. Before 1997, the commercial paper data are based on a survey of dealers. See text and the data appendix in Gürkaynak et al. (2006) for additional details.
The performance of each of our financial market instruments in forecasting the federal funds rate is reported in Table 2 and summarized in Figure 1. The figure plots the RMSE [Fig. 1(a)] and $R^{2}$ [Fig. 1(b)] from regression (4) as a function of the horizon considered, with each line corresponding to a different market instrument. Overall, the ability of all of the securities to predict the federal funds rate is remarkable, with $R^{2}$ statistics often falling in the $60-75 \%$ range. (All the instruments have a higher $R^{2}$ statistic at a two-month horizon than at a one-month horizon. This is due to the fact that there is little systematic variation in the dependent variable to explain at a horizon of only one month-indeed, the next policy meeting is a full three weeks away on average. The RMSE is strictly increasing with the length of the forecast horizon for all of our instruments, as one would expect.)

Our results also indicate that federal funds futures dominate all of our other financial market instruments in predicting the federal funds rate at all horizons, with the difference being the most striking at horizons of one to two months. We interpret this result as suggesting that federal funds futures provide the best market-based measure of monetary policy expectations at horizons out to six months. Of the remaining three financial market instruments, term federal funds and term eurodollars have very similar forecasting performance, whereas commercial paper forecasts better than these two at a horizon of one month, about equally at a horizon of two months, and worse at a horizon of three months.

Our findings of a high $R^{2}$ for financial market forecasts at all horizons seems at odds with Rudebusch (2002), who reported that $R^{2}$ falls to 0 rapidly with the forecast horizon. There are two reasons for this discrepancy: First, our sample period (1994-2004) is one in which the federal funds rate was generally easier to forecast (Lange, Sack, and Whitesell 2003; Swanson 2005) than the late 1980s and early 1990s, which make up a large part of Rudebusch's sample. Second, Rudebusch forecasts forward monthly changes in the federal funds rate (i.e., from month $t+n-1$ to $t+n$ ) and reports $R^{2}$ values for those changes, whereas we report $R^{2}$ values for the cumulative change in the funds rate from month $t$ to $t+n$, as in (4). This latter measure corresponds as closely as possible to the markets' ability to forecast the funds rate itself in $n$ months' time

As a benchmark for comparison, the bottom rows of Table 2 report analogous results for a set of Bayesian VAR (BVAR) forecasts of the federal funds rate. The BVAR is based on 12 monthly lags of the funds rate, nonfarm payrolls, and the core CPI, with a prior taken from Robertson and Tallman (2001) and Sims and Zha (1998) that shrinks the coefficients toward independent random walks, toward unit roots more generally, and toward cointegration. As discussed by Sims (1992) and Sims and Zha (1998), Bayesian VARs of this type typically provide superior forecasts of macroeconomic time series relative to standard VARs due to problems of overparameterization and overfitting associated with the latter. To make the time series forecasts as comparable to our financial market forecasts as possible, we use real-time vintage data and real-time (i.e., recursive) estimation of the BVAR at each date $t$. Additional details of the data, estimation, and forecasting methodology for our BVAR are provided in the Appendix. 
Table 2. Monthly Regressions $\left[\overline{f f}_{t+j, t+j+k}-f f_{t}=\alpha+\beta\left(r_{t, t+j, t+j+k}^{m}-f f_{t}\right)+\varepsilon_{t}\right]$

\begin{tabular}{|c|c|c|c|c|c|c|}
\hline & $\alpha$ & $\beta$ & RMSE (bp) & $R^{2}$ & $p$ value, $H_{0}: \beta=1$ & $\begin{array}{l}\text { Average risk premium (bp), } \\
\beta=1 \text { imposed }\end{array}$ \\
\hline \multicolumn{7}{|c|}{ Term federal funds } \\
\hline One-month & $-.019(-.74)$ & $.69(8.16)$ & 13.1 & .52 & .00 & $10.2(9.03)$ \\
\hline Three-month & $-.242(-3.30)$ & $1.00(8.01)$ & 25.7 & .69 & .97 & $24.0(6.75)$ \\
\hline Four-month & $-.315(-2.89)$ & $1.12(6.29)$ & 36.2 & .64 & .49 & $25.0(4.47)$ \\
\hline Five-month & $-.390(-2.61)$ & $1.12(5.84)$ & 46.1 & .60 & .54 & $31.2(4.08)$ \\
\hline One-month & $-.016(-1.38)$ & $.94(17.86)$ & 9.1 & .73 & .24 & $2.6(3.13)$ \\
\hline Two-month & $-.077(-2.51)$ & 1.06 (12.05) & 15.6 & .75 & .51 & $6.1(3.23)$ \\
\hline Three-month & $-.124(-2.20)$ & $1.11(8.75)$ & 24.2 & .71 & .40 & $8.6(2.47)$ \\
\hline Four-month & $-.177(-2.02)$ & $1.14(6.79)$ & 34.5 & .66 & .41 & $12.1(2.23)$ \\
\hline Five-month & $-.240(-1.86)$ & $1.14(5.58)$ & 45.0 & .60 & .50 & $17.2(2.15)$ \\
\hline Six-month & $-.305(-1.68)$ & $1.12(4.52)$ & 56.6 & .54 & .64 & $23.7(2.15)$ \\
\hline \multicolumn{7}{|c|}{ Eurodollar deposits } \\
\hline Five-month & $-.436(-2.74)$ & 1.14 (5.77) & 46.1 & .60 & .47 & $33.5(4.49)$ \\
\hline Six-month & $-.460(-2.14)$ & $1.07(4.17)$ & 58.4 & .52 & .78 & $40.9(3.59)$ \\
\hline \multicolumn{7}{|c|}{ Commercial paper } \\
\hline One-month & $.013(.74)$ & $.72(11.35)$ & 10.6 & .63 & .00 & $5.3(5.94)$ \\
\hline Two-month & $-.065(-1.81)$ & $.90(9.63)$ & 18.5 & .65 & .28 & $9.7(4.68)$ \\
\hline Three-month & $-.145(-1.94)$ & $.95(6.47)$ & 28.4 & .61 & .73 & $16.6(3.92)$ \\
\hline \multicolumn{7}{|l|}{ Bayesian VAR } \\
\hline One-month & - & - & 16.9 & .18 & - & - \\
\hline Two-month & - & - & 29.9 & .20 & - & - \\
\hline Three-month & - & - & 42.2 & .21 & - & - \\
\hline Four-month & - & - & 53.7 & .21 & - & - \\
\hline Five-month & - & - & 65.1 & .20 & - & - \\
\hline Six-month & - & - & 76.7 & .17 & - & - \\
\hline
\end{tabular}

NOTE: Sample period: 1994:1-2004:12 at monthly frequency, sampled the next-to-last business day of the month; number of observations is $132-n$, where $n$ is the forecast horizon in months. $t$ statistics are reported in parentheses and use Newey-West heteroscedasticity- and autocorrelation-consistent standard errors. The BVAR is estimated recursively from 1985:1 to each forecast date $t$; RMSE and $R^{2}$ for the BVAR are for 1994:1-2004:12 and $R^{2}$ is for changes from $t$ to $t+n$, just as for the financial market-based forecasts. See text for details.

As can be seen in Table 2, all of the financial market-based forecasts clearly outperform BVAR-based forecasts of the federal funds rate at all horizons. The RMSE statistics are 25-50\% lower, and the $R^{2}$ values typically three times higher, for the financial market-based forecasts relative to the BVAR forecasts. (The $R^{2}$ values for the BVAR are for changes in the funds rate from time $t$ to time $t+n$, just as for our financial market instruments. Note that a random walk would have an $R^{2}$ of 0 by this measure.) The superior predictive power of federal funds futures has also been shown by Piazzesi and Swanson (2004), relative to a random walk and $\mathrm{AR}(1)$ forecasts, and by Evans (1998), relative to an estimated Taylor-type rule.

Of course, as discussed previously, the financial instruments contain risk premia that can drive a wedge between their prices and funds rate expectations. The estimated average risk premium at each horizon for each instrument is reported in Table 2 and graphed in Figure 1. For many of these instruments, the estimated average risk premia are fairly large, amounting to almost 10 basic points (bp) per month for term federal funds and term eurodollar deposits. The premia on these last two instruments, in particular, may largely reflect compensation for the risk of counterparty default-indeed, federal funds futures, which are virtually free of counterparty risk, have by far the smallest risk premia of all the financial market instruments in the table. We do not take a stand in this article on the source of the remaining estimated risk premia in federal funds futures (Piazzesi and Swanson 2004 discuss the issue in more detail). We do note, however, that the generally falling level of interest rates over our sample raises the possibility that market participants overpredicted the funds rate on average, and that any such error would boost the measured risk premia.

Note, too, that the hypothesis that $\beta=1$, which we impose to estimate the risk premia, is generally not rejected for any of our securities, except at the one-month-ahead horizon for securities other than federal funds futures. Although time-varying risk premia may be a factor in the poorer forecasting performance of term federal fund loans, term eurodollar deposits, and commercial paper relative to federal funds futures, our results suggest that this variation is not correlated enough with (or large enough relative to) the interest rate spreads on the right side of (4) to drive our estimated coefficients very far from unity.

In Table 3 we investigate to what extent a linear combination of our four financial market instruments might outperform federal funds futures by placing all four financial market instruments on the right side of regression (4). At all horizons, only the federal funds futures rate is ever significant, suggesting that the other securities have little, if any, additional predictive power. In the bottom panel of the table, for each instrument we perform an "encompassing" test of the joint hypothesis that the coefficients on all the other securities are 0 . As is evident from 
(a)

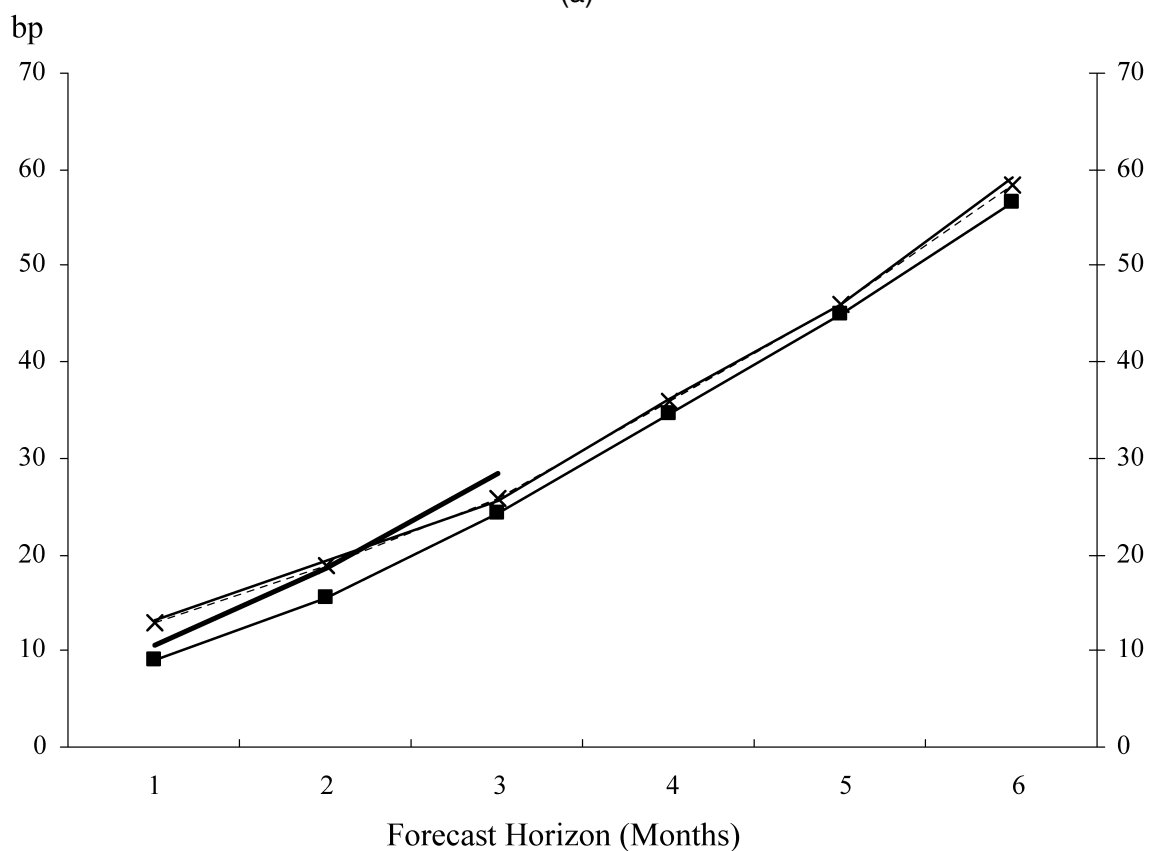

(b)

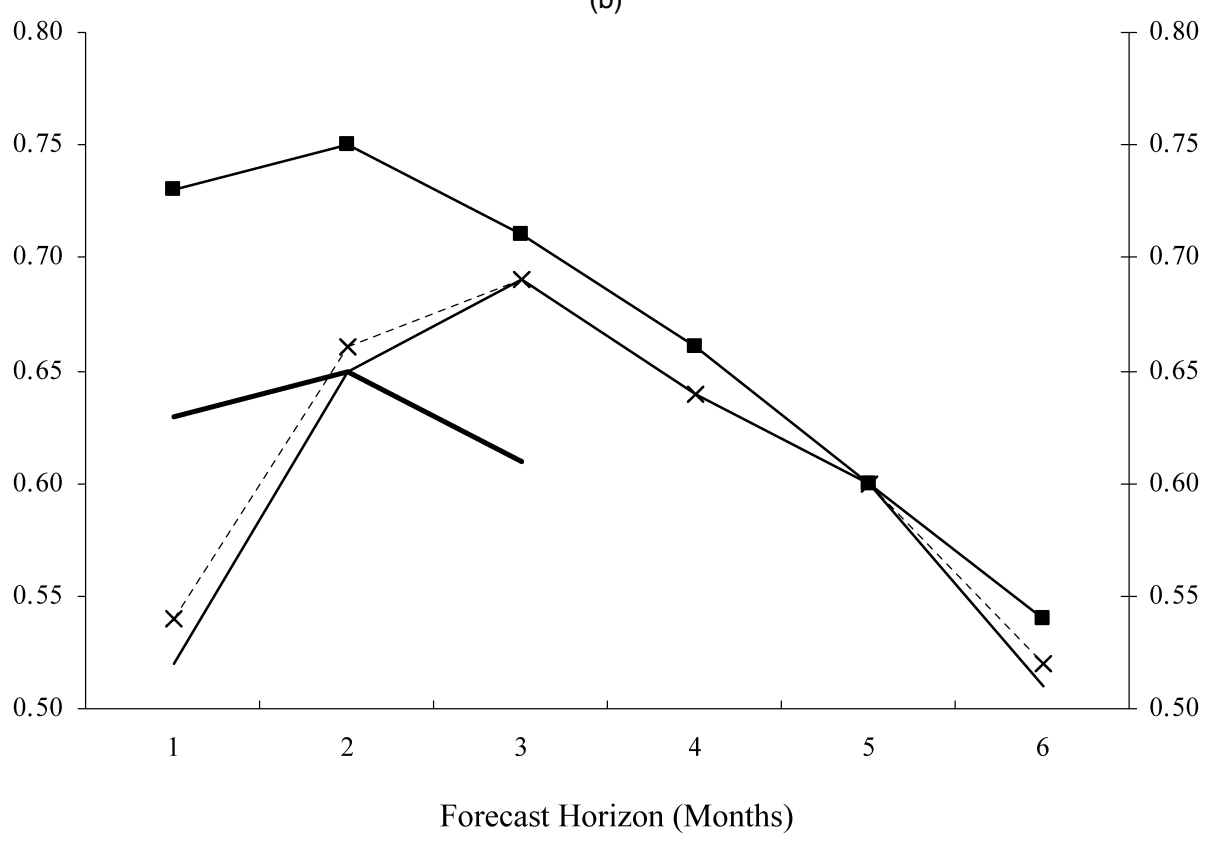

Figure 1. Monthly Regressions. (a) Root mean squared error; (b) regression $R^{2}$. (—— federal funds futures; - - - - - eurodollar deposits; commercial paper.)

the table, we typically cannot reject the hypothesis that the federal funds futures rate encompasses all of the information contained in the other instruments, whereas we typically do reject the hypothesis that any of the other securities can stand on their own. We also experimented with the methods for combining forecasts described in Clemen and Winkler (1986) and could not reject the hypothesis that federal funds futures performed as well as those forecast combination measures. These results lend additional support to our conclusion that federal funds futures dominate all of our other market-based measures of monetary policy expectations (and the BVAR) at horizons out to six months.

\subsection{Results for Quarterly Frequency Instruments}

Our second set of regressions considers instruments that forecast quarterly averages of the federal funds rate at horizons extending out to one year. Of course, moving from monthly to quarterly frequency decreases the number of observations in our sample, but as noted previously, two of our financial market instruments (eurodollar futures and Treasury bills) cannot be used to compute forecasts of the federal funds rate over anything finer than a quarterly window. For these regressions, we sample the data on the next-to-last business day before the expiration of eurodollar futures contracts (typically about two weeks 
Table 3. Forecasts Using Multiple Financial Market Instruments (monthly regressions)

\begin{tabular}{lcccccc}
\hline \hline & \multicolumn{7}{c}{ Horizon (months) } \\
\cline { 2 - 7 } & 1 & 2 & 3 & 4 & 5 & 6 \\
\hline Coefficients & & & & & & \\
Term federal funds & -.27 & -.00 & .31 & .27 & .43 & .30 \\
& $(-1.08)$ & $(-.00)$ & $(1.07)$ & $(.56)$ & $(1.29)$ & $(.81)$ \\
Federal funds futures & 1.14 & 1.29 & .85 & .77 & .48 & .92 \\
& $(7.13)$ & $(6.14)$ & $(3.04)$ & $(2.17)$ & $(1.42)$ & $(1.97)$ \\
Eurodollar deposits & .06 & -.13 & .13 & .10 & .23 & -.10 \\
& $(.26)$ & $(-.49)$ & $(.53)$ & $(.19)$ & $(.46)$ & $(-.26)$ \\
Commercial paper & .03 & -.09 & -.18 & - & - & - \\
& $(.24)$ & $(-.51)$ & $(-1.28)$ & & & \\
Encompassing tests $(p$ value) & & & & & & \\
Term federal funds & .000 & .000 & .002 & .022 & .014 & .048 \\
Federal funds futures & .176 & .650 & .007 & .621 & .237 & .662 \\
Eurodollar deposits & .000 & .000 & .000 & .067 & .071 & .000 \\
Commercial paper & .000 & .000 & .000 & - & - & - \\
\hline
\end{tabular}

NOTE: The note to Table 2 applies. Regressions include all four financial market instruments on the right side. Encompassing tests are for the joint restriction that all other financial market instruments in the regression have a zero coefficient.

before the end of the quarter), except for federal funds futures, which we sample on the next-to-last business day of the quarter. (Ideally, we would like to synchronize our federal funds futures forecasts with our eurodollar futures forecasts, but this is not possible because federal funds futures always expire at the end of the month and eurodollar futures about two weeks before the end of the quarter.)
Results are reported in Table 4 and summarized in Figure 2. Again, all of our financial market instruments clearly dominate Bayesian VAR-based forecasts of the federal funds rate, but this time the forecasting performance across our various financial instruments is more similar, with federal funds futures and term federal funds performing the best at short horizons and term federal funds, term eurodollars, and eurodollar futures all performing about equally well at horizons of three or four quarters. One might worry that this is because all of our instruments forecast poorly at long horizons, but this is not the case-indeed, all three instruments have $R^{2}$ values of about $40 \%$ in regression (4), which is substantial for a one-year-ahead forecast. Again, the hypothesis that $\beta=1$ is not rejected for any of our securities at any horizon.

One interesting observation that emerges from the table is that commercial paper and Treasury bills forecast relatively poorly in the near term, despite the fact that they have among the smallest average risk premia of all our financial market instruments-indeed, the estimated average risk premium on Treasury bills is highly negative at the one-quarter horizon, reflecting the tax advantages of these securities and a willingness of investors to pay a premium for their unparalleled safety and very high liquidity. This finding highlights the fact that a smaller average risk premium and high liquidity do not necessarily lead to better forecasting performance.

Table 5 presents results from multivariate forecasting regressions with all of our financial market instruments except federal

Table 4. Quarterly regressions $\left[\overline{f f}_{t+j, t+j+k}-f f_{t}=\alpha+\beta\left(r_{t, t+j, t+j+k}^{m}-f f_{t}\right)+\varepsilon_{t}\right]$

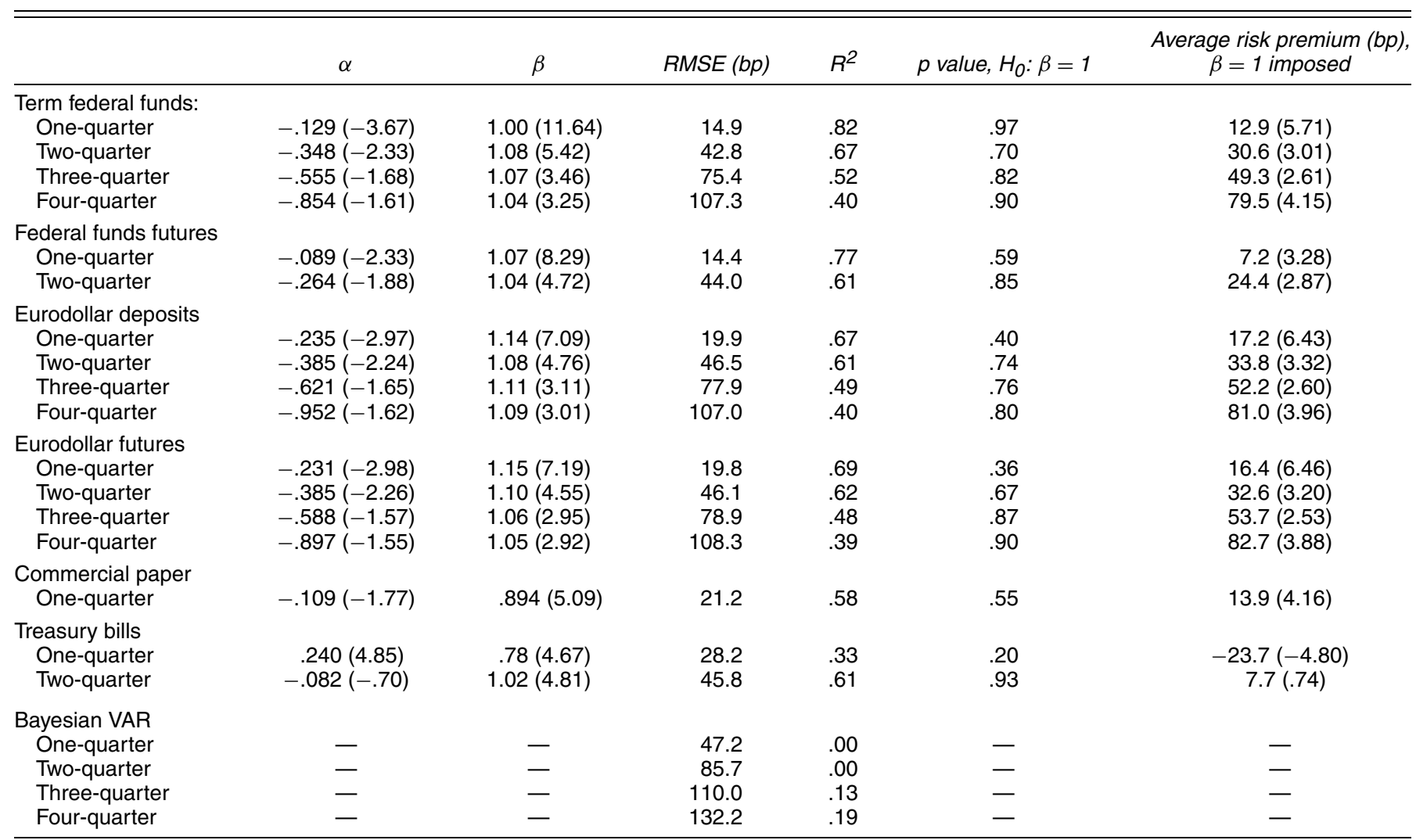

NOTE: Sample period: 1994:1-2004:4 at quarterly frequency, sampled the next-to-last business day before the expiration of eurodollar futures (about two weeks before the end of the quarter), except for federal funds futures, which are sampled the next-to-last business day of the quarter; number of observations is $44-n$, where $n$ is the forecast horizon in quarters. $t$ statistics are reported in parentheses and use Newey-West heteroscedasticity- and autocorrelation-consistent standard errors. The BVAR is estimated recursively from $1985: 1$ to each forecast date $t$; RMSE and $R^{2}$ for the BVAR are for 1994:1-2004:4 and $R^{2}$ is for changes from $t$ to $t+n$, just as for the financial market-based forecasts. See text for details. 
(a)

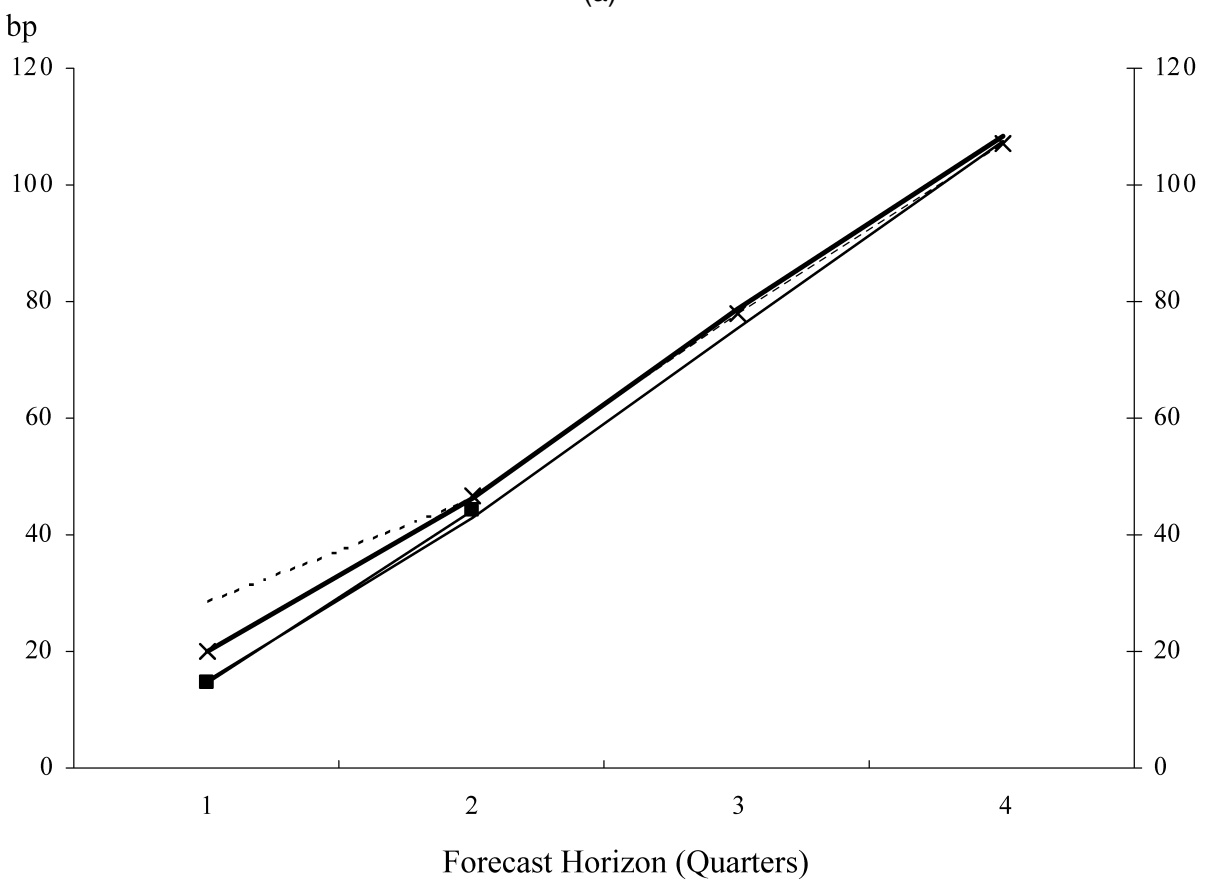

(b)

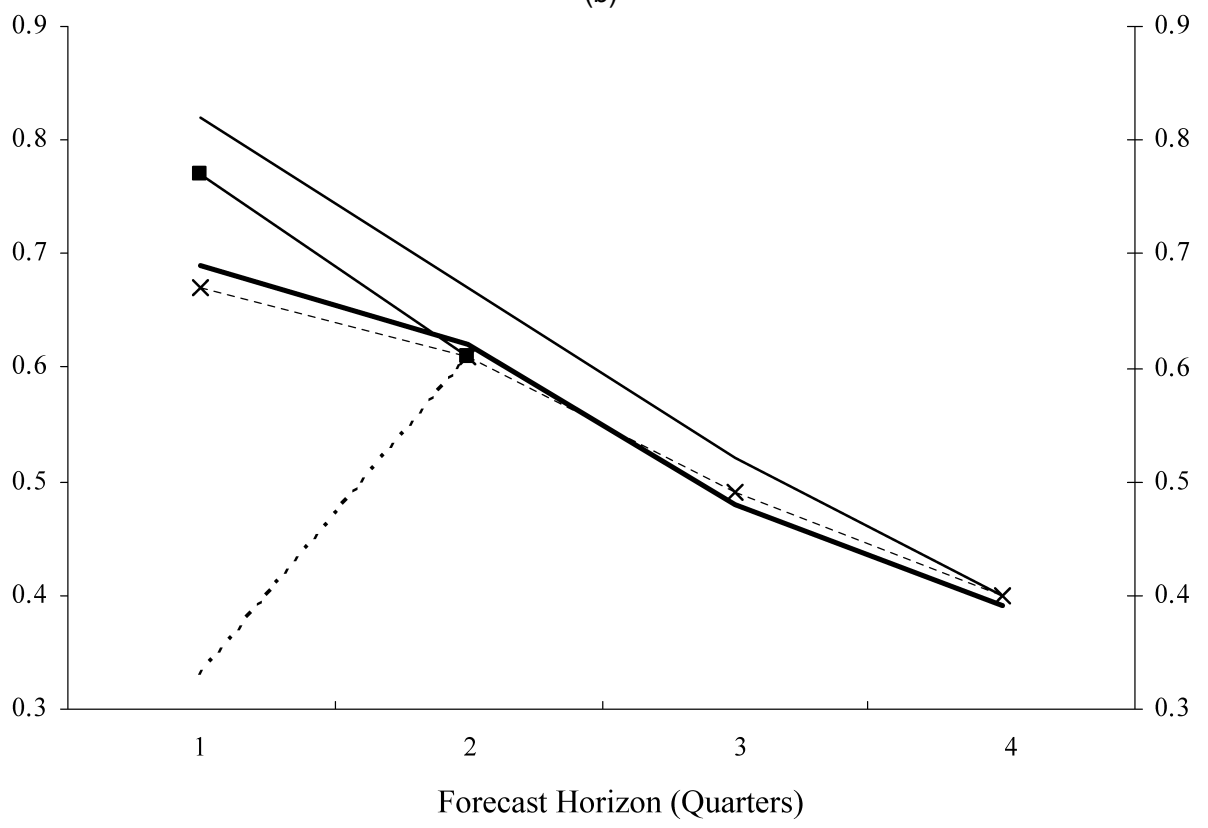

Figure 2. Quarterly Regressions. (a) Root mean squared error; (b) regression $R^{2}$. --- X-- eurodollar deposits; eurodollar futures; . . . . . . treasury bills.)

term federal funds;

funds futures on the right side (we omit federal funds futures because we are not able to sample them on the same day with the same horizon as eurodollar futures and the other instruments). In general, no one instrument stands out as dominating or consistently encompassing the others. Although term federal funds rates fare a bit better in the encompassing tests, at the fourquarter-ahead horizon we still cannot reject the hypothesis that any of the three available instruments is a sufficient statistic for the other two. This finding may reflect a stronger tendency of financial markets to price these securities off of one another at longer maturities. Finally, the optimal linear combination of the securities varies dramatically from one column of the table to the next, suggesting that none of these estimated linear combinations will provide forecasts of the federal funds rate that are very robust. Going forward, then, one is probably best advised to use one of these instruments-or at most a simple average of two or three of them-for measuring monetary policy expectations at longer horizons.

\section{MONETARY POLICY SHOCKS}

The results in the previous section indicate that federal funds futures provide useful measures of monetary policy expec- 
Table 5. Forecasts Using Multiple Financial Market Instruments (quarterly regressions)

\begin{tabular}{lcccc}
\hline \hline & \multicolumn{4}{c}{ Horizon (quarters) } \\
\cline { 2 - 5 } & 1 & 2 & 3 & 4 \\
\hline Coefficients & & & & \\
Term federal funds & 1.17 & 1.82 & 1.41 & .27 \\
& $(13.98)$ & $(5.91)$ & $(2.38)$ & $(.24)$ \\
Eurodollar deposits & -.76 & -3.82 & -.52 & .46 \\
& $(-.59)$ & $(-3.18)$ & $(-.46)$ & $(.23)$ \\
Eurodollar futures & 1.09 & 2.53 & .15 & .33 \\
& $(.88)$ & $(2.26)$ & $(.19)$ & $(.18)$ \\
Treasury bills & .35 & .47 & - & - \\
& $(3.18)$ & $(.92)$ & & \\
Commercial paper & -.73 & - & - & - \\
& $(-2.22)$ & & & \\
Encompassing tests $(p$ value) & & & & \\
Term federal funds & .002 & .010 & .893 & .834 \\
Eurodollar deposits & .000 & .000 & .054 & .943 \\
Eurodollar futures & .000 & .000 & .011 & .915 \\
Treasury bills & .000 & .000 & - & - \\
$\quad$ Commercial paper & .000 & - & - & -
\end{tabular}

NOTE: The note to Table 4 applies. Regressions include all four financial market instruments on the right side. Encompassing tests are for the joint restriction that all other financial market instruments in the regression have a zero coefficient.

tations. However, in many applications one is interested in changes in policy expectations, such as around FOMC announcements or macroeconomic data releases. Indeed, as noted in Section 1, changes in market-based measures of monetary policy expectations around FOMC announcements have been used by a number of authors as measures of monetary policy shocks (e.g., Faust et al. 2004 discussed how the surprise component of monetary policy announcements can be used to help identify the effects of monetary policy shocks in a VAR). In this section, we discuss how to measure the surprise component of monetary policy announcements using federal funds futures, given that we found these rates provide the best measure of near-term monetary policy expectations.

A small complication that arises with federal funds futures is that these rates are based on the average federal funds rate that is realized for the calendar month specified in the contract. Thus, if an FOMC announcement is scheduled to take place on day $d 1$ of month $t$, the implied rate from the current-month federal funds futures contract, $f f 1$, the day before is a weighted average of the federal funds rate that has prevailed so far in the month, $r_{0}$, and the rate that is expected to prevail for the reminder of the month, $r_{1}$, plus a risk premium:

$$
f f 1_{t, d 1-1}=\frac{d 1}{D 1} r_{0}+\frac{D 1-d 1}{D 1} E_{t, d 1-1} r_{1}+\rho 1_{t, d 1-1},
$$

where $D 1$ denotes the number of days in month $t, E_{t, d 1-1}$ denotes the mathematical expectation conditional on information from day $d 1-1$ of month $t$, and $\rho 1$ denotes any risk premium that may be present in the contract. By leading this equation ahead one day and differencing, we can compute the surprise component of the change in the federal funds rate target- that is, $E_{t, d 1} r_{1}-E_{t, d 1-1} r_{1}$. This measure, which we call $m p 1$, is given by

$$
m p 1_{t}=\left(f f 1_{t, d 1}-f f 1_{t, d 1-1}\right) \frac{D 1}{D 1-d 1},
$$

which is the scaled change in the current-month federal funds futures contract around the FOMC announcement, and is the same as that used by Kuttner (2001). Note that to interpret (6) as the surprise change in monetary policy expectations, we need to assume that the change in the risk premium $\rho 1$ in this narrow window of time is negligible in comparison to the change in expectations itself. Piazzesi and Swanson (2004) provided some evidence that this assumption is consistent with the data. Note also that for FOMC meetings that occur very late in the month (i.e., in the last seven days of the month), we use the unscaled change in the next-month federal funds futures contract to avoid multiplying by a very large scale factor in (6), which could unduly magnify changes in bid-ask spreads or other factors.

Although the policy shocks $m p 1$ likely provide the best measure of unexpected changes to the immediate policy setting, they might be affected by shifts in the timing of policy actions. For example, financial markets might view a federal funds rate tightening in the near future as very likely, but be unsure as to whether the FOMC will act at the current meeting or the meeting after. An alternative measure of monetary policy shocks that is less affected by these timing issues can be constructed by applying a similar procedure to measure changes in expectations about $r_{2}$, the federal funds rate target that will prevail after the second FOMC meeting from now. Let $f f 2$ denote the federal funds futures rate for the month containing the second FOMC meeting (typically the three-month-ahead contract). Then

$f f 2_{t, d 1-1}=\frac{d 2}{D 2} E_{t, d 1-1} r_{1}+\frac{D 2-d 2}{D 2} E_{t, d 1-1} r_{2}$

$$
+\rho 2_{t, d 1-1},
$$

where $d 2$ and $D 2$ are the day of that second FOMC meeting and the number of days in the month containing that FOMC meeting, respectively, and $\rho 2$ denotes any risk premium in the contract. By leading this equation ahead one day and differencing, the change in expectations for the second FOMC meeting, which we call $m p 2$, is given by

$$
m p 2_{t}=\left[\left(f f 2_{t, d 1}-f f 2_{t, d 1-1}\right)-\frac{d 2}{D 2} m p 1_{t}\right] \frac{D 2}{D 2-d 2} .
$$

Figure 3 compares the two shock measures $m p 1$ and $m p 2$ in a scatterplot. As is clear in the figure, the two measures are generally very highly correlated with each other, lying along the $45^{\circ}$ line. However, the shocks differ considerably on a handful

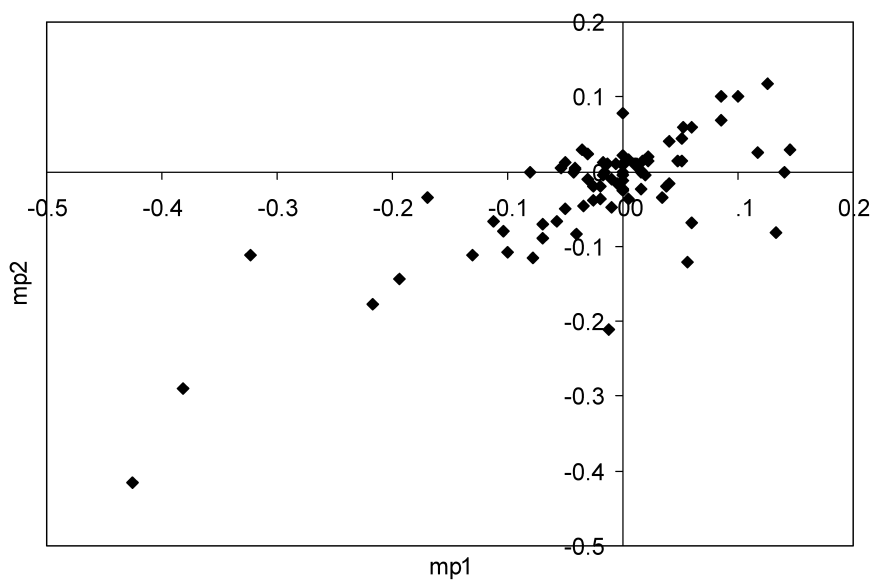

Figure 3. Comparison of Monetary Policy Shock Measures (mp1 vs. mp2). 
of dates, which we interpret as dates on which the FOMC's action was largely a surprise in timing as opposed to a surprise in the level of the federal funds rate going forward.

To investigate this issue further, we perform a simple exercise that decomposes the policy shocks into two components: one that influences the general level of policy expectations (the "level" factor) and one that represents shifts in the timing of policy actions at the two meetings (the "timing" factor). Formally, the decomposition is as follows:

$$
\left[\begin{array}{l}
m p 1_{t} \\
m p 2_{t}
\end{array}\right]=\left[\begin{array}{ll}
1 & 1 \\
\alpha & 0
\end{array}\right]\left[\begin{array}{c}
\text { level }_{t} \\
\text { timing }_{t}
\end{array}\right] .
$$

Note that increases in either factor, level or timing, push up the current FOMC policy shock $m p 1_{t}$. An increase in level results in a shift to the expected level of the interest rate going forward, with the rate after the second FOMC meeting from today going up by an amount $\alpha$. By contrast, an increase in timing has no effect on the level of the federal funds rate expected after the subsequent FOMC meeting, but only on the timing of policy actions across the two meetings.

We solve this decomposition based on the variance-covariance matrix from the observed policy shocks, under the assumption that the two factors are orthogonal. The estimated value of $\alpha$ is 1.11 , suggesting that the level factor is a nearly parallel shift in the policy outlook. Both types of shocks are sizable: The standard deviation of level shocks is 7.4 basis points, compared to 6.6 basis points for timing shocks. The measure $m p 1$ is strongly influenced by these timing shocks, which account for $44 \%$ of its variance over the sample. The measure $m p 2$, by construction, is not influenced at all by the timing shocks.

Note that (9) can be inverted to yield level and timing in terms of the observable $m p 1$ and $m p 2$ :

$$
\left[\begin{array}{c}
\text { level }_{t} \\
\text { timing }_{t}
\end{array}\right]=\left[\begin{array}{cc}
0 & 1 / \alpha \\
1 & -1 / \alpha
\end{array}\right]\left[\begin{array}{c}
m p 1_{t} \\
m p 2_{t}
\end{array}\right],
$$

which, because we estimate $\alpha \approx 1$, corresponds very closely to the "rule of thumb" definition of level and timing components of monetary policy announcements used by Bernanke and Kuttner (2005).

Figure 4 plots a time series of the realized values of these two factors since 1994. One observation that stands out is that timing shocks were more sizable early in the sample, particularly in 1994 and 1995. This finding might reflect the shift in the behavior of the FOMC beginning in 1994, when it began to make policy moves predominantly at FOMC meetings. The results suggest that it might have taken market participants some time to fully recognize this shift in behavior. In recent years, some of the largest timing surprises have taken place at intermeeting policy moves. Indeed, two of the three sizable timing shocks in 2001 took place on January 3 and September 17.

\section{CONCLUSIONS}

Three notable results emerge from this article. First, all of the financial market instruments we consider provide forecasts of the federal funds rate that clearly dominate standard time series forecasts. Root mean squared errors for our financial marketbased forecasts are typically about half the size of the time series forecasts, and the $R^{2}$ for funds rate changes is dramatically higher.

Second, federal funds futures dominate other market-based measures of monetary policy expectations at horizons out to six months. Their predictive power for the future federal funds rate is higher, their average risk premium is lower, and we cannot reject the hypothesis that they encompass the information contained in all of our other market-based forecast measures combined.

Third, for horizons of six months to one year, term federal funds, term eurodollars, and eurodollar futures all seem to forecast about equally well. This latter finding may partly reflect the degree to which these financial markets are integrated with one another.

These findings have important implications for the computation of monetary policy shocks. For changes in the very nearterm stance of policy, our results support measures based on federal funds futures. However, we presented some statistical evidence that shocks computed from the current-month federal funds futures contract may be influenced by changes in the timing of policy actions that do not influence the expected course of the federal funds rate beyond a horizon of about six weeks. We, thus, presented an alternative shock measure that captures changes in market expectations of the course of monetary policy over slightly longer horizons, which may be more useful for many purposes.

It is our hope that this article will serve as a reference and encourage the use of market-based measures of monetary policy expectations, including in particular the use of these instruments to compute monetary policy surprises around FOMC announcements and changes in market expectations for monetary policy in response to other macroeconomic data and news releases.

\section{ACKNOWLEDGMENTS}

We thank Kenneth Kuttner, William Nelson, David Small, two anonymous referees, and the editor for valuable comments and suggestions, Ellis Tallman for computer code and helpful discussions regarding BVAR forecasts of the fed funds rate, and Emily Cauble and Andrew Marder for excellent research assistance. The opinions expressed in this article should be regarded as solely those of the authors and do not necessarily reflect the views of the management of the Federal Reserve Bank of San Francisco or any other person in the Federal Reserve System.

\section{APPENDIX: BAYESIAN VAR DATA, ESTIMATION, AND FORECASTING METHODOLOGY}

To compute time series forecasts of the federal funds rate in Section 4, we use a Bayesian VAR, because these have been found by Sims (1992) and others to provide better forecasts of typical macroeconomic time series than standard VAR's or univariate autoregressions. In this appendix we provide the details regarding the data, estimation, and forecasting methodology for the BVAR we employ. 
Feb 1994 to May 1999

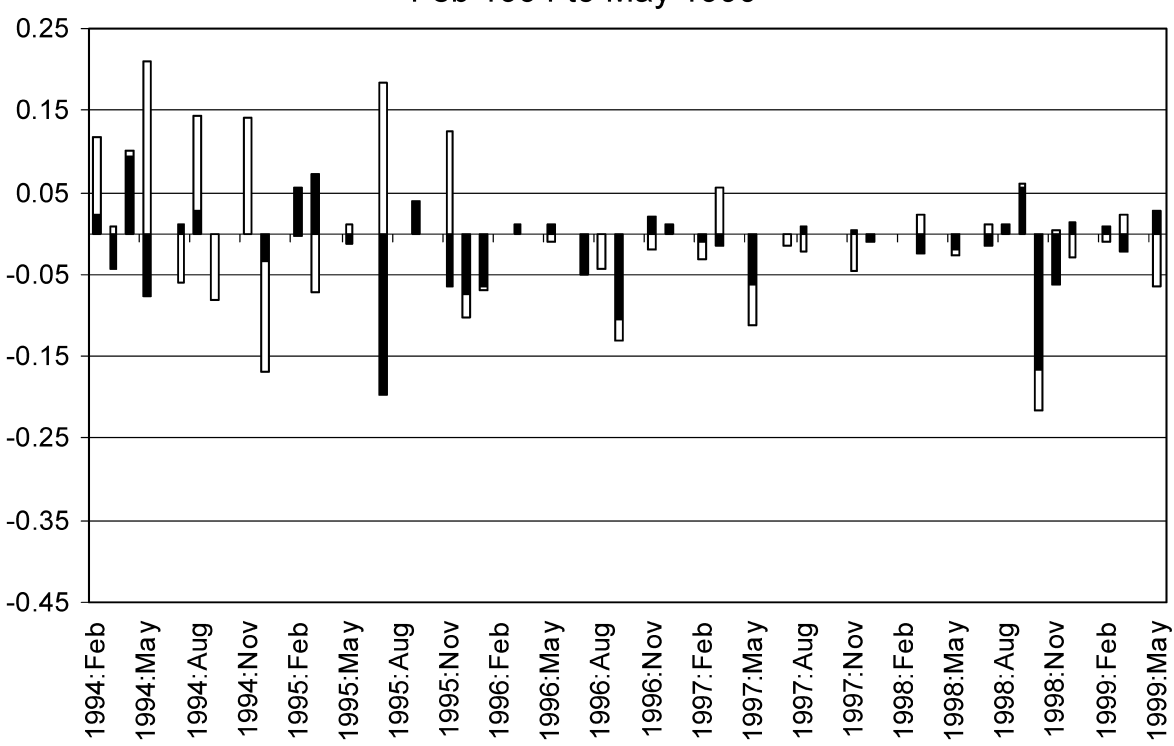

June 1999 to December 2004

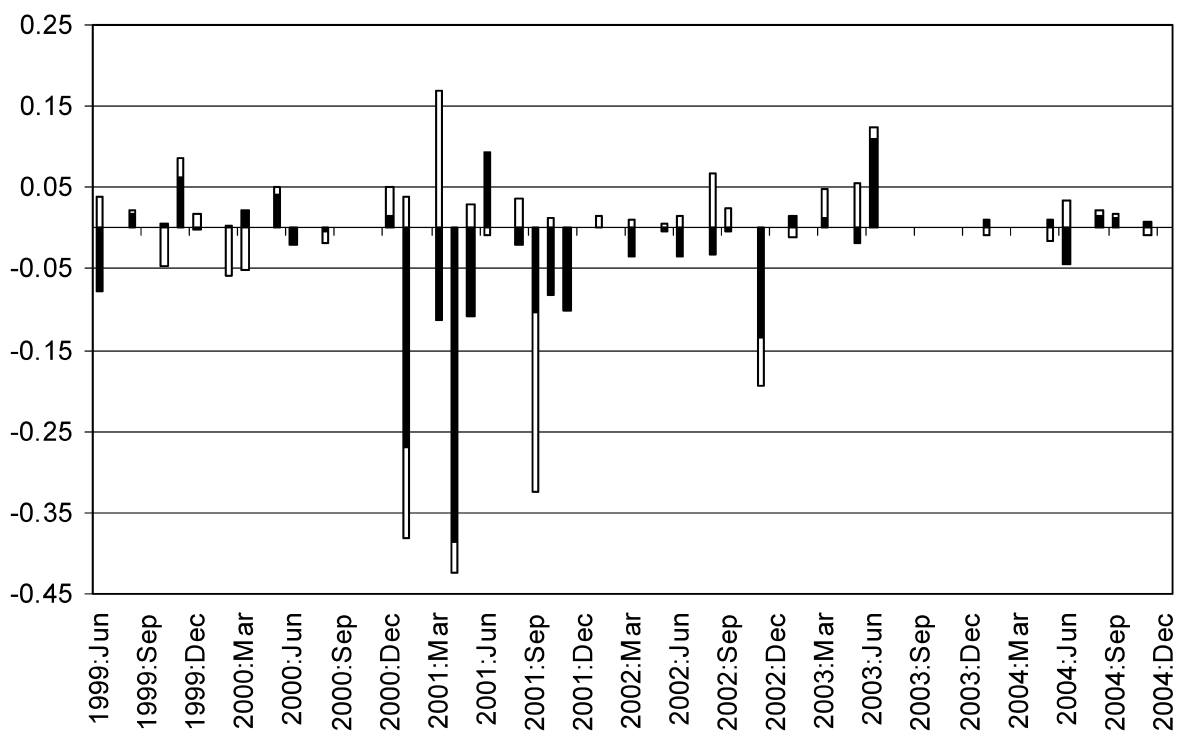

Figure 4. Decomposition of Monetary Policy Shocks ( $\square$ timing; $\square$ path).

\section{Data}

We base our BVAR on three variables: the federal funds rate, nonfarm payrolls, and the core CPI. We experimented with including additional variables, such as a monthly gross domestic product (GDP) series or monetary aggregates, but these never resulted in noticeable improvements in the federal funds rate forecasts over our 1994-2004 sample.

We begin our sample in January 1985. Many authors (e.g., Bernanke and Mihov 1998) have estimated one or more structural breaks in monetary policy in the early 1980s, so to reduce the possibility of specification error we begin our estimation after the last of these estimated breakpoints and after the end of the Volcker disinflation of the early 1980s. We also experimented with extending the estimation period back to about 1960, but this never led to noticeable improvements in the federal funds rate forecasts over the 1994-2004 period.

At the end of each month $t$, the federal funds rate for month $t$ is known, but the level of nonfarm payrolls and the core CPI is only known for month $t-1$ due to lags of a few weeks in the release of these statistics. To make the information sets underlying our BVAR forecasts as comparable as possible to those underlying our financial market forecast data, we use values of the federal funds rate through date $t$ and of nonfarm payrolls and the core CPI through date $t-1$ in the BVAR. Moreover, we use the real-time vintage of these data series. Core CPI is not revised (except on rare occasion) and, thus, is known in real time, but we use the level of nonfarm payrolls as it was first reported, rather than the final revised value that may not have been computed by the Bureau of Labor Statistics (BLS) until several months or even years after the fact.

\section{Estimation}

We experimented with estimating the BVAR both in levels and in changes and found that the latter performed much better for forecast horizons of six months or less. In particular, we used the month-to-month first difference of the federal 
funds rate, the year-on-year log change in the core CPI, and the year-on-year log change in nonfarm payrolls. We used the yearon-year change for the latter two variables because the monthto-month changes in those series tend to be very noisy, which would tend to bias coefficients downward.

For monthly data, we estimated the BVAR on 12 lags using a prior taken from Sims and Zha (1998) and Robertson and Tallman (2001). In particular, we used a Normal-Flat prior with the seven hyperparameters discussed in the RobertsonTallman set as follows: $\mu_{1}$ (overall scale) $=1, \mu_{2}$ (strength of independent random-walk prior) $=.5, \mu_{3}$ (strength of prior on intercept $)=1, \mu_{4}$ (decay rate on lags) $=5, \mu_{5}$ (strength of independent unit-root prior) $=5$, and $\mu_{6}$ (strength of cointegration prior) $=5$. (We are indebted to Ellis Tallman for providing us with Matlab code for estimating BVARs of this type and for helpful discussions regarding reasonable hyperparameter values for our particular sample and application.) We experimented with values for these hyperparameters quite a bit and found that our forecasts and results were very robust to these changes.

For quarterly data (Table 4) with a forecast horizon of one to two quarters, we estimated the BVAR in first differences, as described previously, using four lags with the seven hyperparameters of the Normal-Flat prior set as follows: $\mu_{1}=1, \mu_{2}=3$, $\mu_{3}=1, \mu_{4}=2, \mu_{5}=0$, and $\mu_{6}=0$. For forecast horizons of three to four quarters, we found that a BVAR in levels performed substantially better, so we estimated the BVAR in levels (log levels for nonfarm payrolls and the core CPI) and set $\mu_{1}=1, \mu_{2}=5, \mu_{3}=1, \mu_{4}=1, \mu_{5}=0$, and $\mu_{6}=0$. Note that for quarterly data we found that the additional "unit root" and "cointegration" hyperparameters only hurt forecast performance relative to a more standard Minnesota-style specification.

At each date $t$ from January 1994 through November 2004, we reestimate the BVAR on data running from 1985 through $t$, taking account of the data availability and real-time vintage issues discussed previously. Thus, our time series forecasts are based on information that mirrors as closely as possible the information underlying our financial market data.

Finally, it is worth noting that, despite our use of real-time data and recursive estimation, all of our BVAR forecasts have benefited from hindsight through our choice of specification and hyperparameter values. Thus, our BVAR forecast results should probably be regarded as something of an ideal time series-based forecast that would have been very difficult to actually achieve in real time. The fact that our financial marketbased forecasts still compare so favorably to the BVAR-based forecasts is a further sign of their high quality.

\section{Forecasting}

Our forecasts are computed as one would compute forecasts from a standard VAR. At each date $t$, we estimate a coefficient matrix $B$ for the BVAR and then compute our forecasts for $x_{t+1}, x_{t+2}, \ldots$ by projecting the system forward from date $t$, so that $\hat{x}_{t+1}=B x_{t}, \hat{x}_{t+2}=B^{2} x_{\mathrm{t}}, \ldots$. For those forecasts that were done in first differences for the federal funds rate, we arrive back at a funds rate level forecast by cumulating the firstdifference forecasts forward.

\section{[Received September 2004. Revised March 2006.]}

\section{REFERENCES}

Bernanke, B., and Kuttner, K. (2005), "What Explains the Stock Market's Reaction to Federal Reserve Policy?" Journal of Finance, 60, 1221-1259.

Bernanke, B., and Mihov, I. (1998), "Measuring Monetary Policy," Quarterly Journal of Economics, 133, 869-902.

Bomfim, A. (2003), "Pre-Announcement Effects, News Effects, and Volatility: Monetary Policy and the Stock Market," Journal of Banking and Finance, 27, 133-151.

Brunner, A. D. (2000), "On the Derivation of Monetary Policy Shocks: Should We Throw the VAR Out With the Bath Water?" Journal of Money, Credit, and Banking, 32, 254-279.

Campbell, J., Lo, A., and MacKinlay, C. (1997), The Econometrics of Financial Markets, Princeton, NJ: Princeton University Press.

Clemen, R. T., and Winkler, R. L. (1986), "Combining Economic Forecasts," Journal of Business \& Economic Statistics, 4, 39-46.

Cochrane, J. H., and Piazzesi, M. (2002), "The Fed and Interest Rates: A High Frequency Identification," American Economic Review Papers and Proceedings, 92, 90-101.

Downing, C., and Oliner, S. (2004), "The Term Structure of Commercial Paper Rates," Federal Reserve Board Finance and Economics Discussion Series 2004-18.

Ellingsen, T., and Soderstrom, U. (2004), "Monetary Policy and the Bond Market," unpublished manuscript, IGIER.

Evans, C. (1998), "Real-Time Taylor Rules and the Federal Funds Futures Market," Economic Perspectives, 22, 44-55.

Faust, J., Swanson, E., and Wright, J. H. (2004), "Identifying VARs Based on High Frequency Futures Data," Journal of Monetary Economics, 51, $1107-1131$.

Gürkaynak, R., Sack, B., and Swanson, E. (2002), "Market-Based Measures of Monetary Policy Expectations," Federal Reserve Board Finance and Economics Discussion Series 2002-40.

(2006), "Market-Based Measures of Monetary Policy Expectations,' Working Paper 2006-04, Federal Reserve Bank of San Francisco.

Krueger, J. T., and Kuttner, K. N. (1996), "The Fed Funds Futures Rate as a Predictor of Federal Reserve Policy," Journal of Futures Markets, 16, 865-879.

Kuttner, K. (2001), "Monetary Policy Surprises and Interest Rates: Evidence From the Fed Funds Futures Market," Journal of Monetary Economics, 47, 523-544.

Lange, J., Sack, B., and Whitesell, W. (2003), "Anticipations of Monetary Policy in Financial Markets," Journal of Money, Credit, and Banking, 35, 889-909.

Piazzesi, M., and Swanson, E. (2004), "Futures Rates as Risk-Adjusted Forecasts of Monetary Policy," Working Paper 10547, National Bureau of Economic Research.

Poole, W., and Rasche, R. H. (2000), "Perfecting the Market's Knowledge of Monetary Policy," Journal of Financial Services Research, 18, 255-298.

Rigobon, R., and Sack, B. (2002), "The Impact of Monetary Policy on Asset Prices," Working Paper 8794, National Bureau of Economic Research.

Robertson, J., and Tallman, E. (2001), "Improving Federal-Funds Rate Forecasts in VAR Models Used for Policy Analysis," Journal of Business \& Economic Statistics, 19, 324-330.

Rudebusch, G. (1998), "Do Measures of Monetary Policy in a VAR Make Sense?" International Economic Review, 39, 907-931.

(2002), "Term Structure Evidence on Interest Rate Smoothing and Monetary Policy Inertia," Journal of Monetary Economics, 49, 1161-1187.

Sims, C. (1992), "Bayesian Inference for Multivariate Time Series With Trend," unpublished manuscript presented at the American Statistical Association meeting, available at www.princeton.edu/ sims.

Sims, C., and Zha, T. (1998), "Bayesian Methods for Dynamic Multivariate Models," International Economic Review, 39, 949-968.

Soderstrom, U. (2001), "Predicting Monetary Policy With Federal Funds Futures Prices," Journal of Futures Markets, 21, 377-391.

Stigum, M. (1990), The Money Market, New York: McGraw-Hill.

Swanson, E. (2005), "Have Increases in Federal Reserve Transparency Improved Private Sector Interest Rate Forecasts?" Journal of Money, Credit, and Banking, 38, 791-819. 